\title{
Platinum-group elements in the Eastern Deccan volcanic province and a comparison with platinum metals of the western Deccan
}

\author{
James Crocket ${ }^{1}$, Dalim Paul ${ }^{2, *}$ and Trisha Lala ${ }^{2}$ \\ ${ }^{1}$ School of Geography and Earth Sciences, McMaster University, Hamilton, Canada. \\ ${ }^{2}$ Department of Geology, Presidency University, Kolkata 700 073, India. \\ ${ }^{*}$ Corresponding author. e-mail: dalimpaul@yahoo.co.in
}

This study is the first detailed investigation of the platinum-group elements (PGE) at the eastern margin of the Deccan volcanic province of India. One of the PGE, osmium, is not included largely because of analytical problems. The study is focused on mafic volcanics and dykes from four areas including Amarkantak, Umaria, Shahdol and Chirimiri. The first two localities represent two lava piles of about 170 and $400 \mathrm{~m}$ thickness respectively. In Umaria, 16 flows have been demarcated based on petrography and field studies. The Shahdol samples are basal lava formations overlying Gondwana sediments (Carboniferous) and the Chirimiri samples are dykes. In this study, the western Deccan province is defined as the Western Ghats plus Kutch. On average, the PGE are 20\% higher in Amarkantak than Umaria and the flows are $\sim 13 \%$ higher in PGE than the dykes. A Zr vs. Pd scattergram found a strong positive correlation for these two elements except for one Umaria sample which indicated severe $\mathrm{Pd}$ loss. A comparison of west and east parts of the Deccan volcanic province using primitive mantle normalization showed that higher values prevailed in the western province suite in the Ni-Ir-Ru-Pt region. In contrast, eastern province values dominated in the $\mathrm{Pd}-\mathrm{Au}-\mathrm{Cu}$ region at the ' $\mathrm{Cu}$ ' end of the profiles. A strong dominance of $\mathrm{Pd}$ in the eastern Deccan was also of interest. A number of factors, for example, percentage partial melting of the source rock and the temperature and pressure of partial melting strongly influence the character of these profiles. The observed PGE profile characteristics probably result in part from a long distance of subsurface transport of Deccan magma from the western to eastern regions.

\section{Introduction}

The abundances of Platinum Group of Elements (PGE) are being documented for petrogenetic evaluation in a number of recent studies (Momme et al. 2002; Qi et al. 2008; Li et al. 2012). These highly siderofile PGE provide valuable insight in the petrogenesis of mantle-derived rocks. The abundances of PGE in ultramafic rocks and stratified igneous complexes are fairly known. In contrast, abundances in continental mafic rocks are not so well known, except the contents of $\mathrm{Pd}$ and Ir. Among the continental flood basalts, only Parana, Karroo and Siberian traps have been studied. Fractional crystallization of mafic magma is known to concentrate Ir, Rh and Os in the early crystallising fractions. Variation in the PGE abundances in the mid-ocean ridge basalts and continental basalts have been linked to the degree of depletion. The Deccan Trap basalts of India are comparable to

Keywords. Platinum group elements; geochemistry; Deccan volcanism; India. 
the Siberian Trap at Noril'sk both in extent and linkage to a plume. Geochemical and petrological studies have established variable crustal contamination in both the provinces (Cox and Hawkesworth 1985; Keays and Lightfoot 2010). The paucity of PGE data in Deccan basalts has, however, precluded an objective modelling.

Recent studies of platinum group elements (PGE) in the Deccan Volcanic Province (DVP) including Crocket and Paul (2004, 2008) and Keays and Lightfoot (2010) provide a basis for assessment of the Deccan flood basalts as potential hosts of magmatic sulfides carrying economic levels of $\mathrm{Ni}, \mathrm{Cu}$ and PGE. These studies are focused exclusively on the western Deccan including the Western Ghats, Saurashtra and Kutch. While recent research on mafic flows and dykes of the eastern Deccan (Paul 2005; Paul et al. 2008) is available, studies with a focus on PGE are lacking. A stimulus for extending the PGE database to a larger portion of the DVP is the enormous economic significance of the Noril'sk/Talnakh camp, USSR where a flood basalt setting is involved. Keays and Lightfoot (2010) argue that basaltic magmas of the Western Ghats did not reach sulfur saturation and consequently were unable to scavenge and concentrate PGE, $\mathrm{Ni}$ and $\mathrm{Cu}$.

The main motivation of the present study is to examine the PGE abundances from hitherto unexplored eastern part of DVP and to explore the similarity or otherwise of the PGE contents in the available data from the western part. It is also our intention to characterize the PGE geochemistry of the associated mafic dykes from the volcanic province.

\section{Field relations and sample details}

The area, which is the focus of the present study, is shown in figure 1 and is referred here as the Eastern Deccan Volcanic Province (EDVP). The distance from the Western Ghats is about $600 \mathrm{~km}$. Four areas were sampled including Umaria, Amarkantak, Shahdol and Chirimiri, all of which are situated in the eastern sector of Madhya Pradesh and Chattisgarh states. The lava pile at Umaria is about $400 \mathrm{~m}$ thick. Geological Survey of India has identified 16 flows forming four formations in the Umaria lava pile. In Umaria, the Deccan flows overlie Gondwana sediments (Permian) that in turn overlie an Archaean basement. The second lava pile sampled is near Amarkantak, about $100 \mathrm{~km}$ southeast of Umaria, has a $5 \mathrm{~m}$ thick, Lameta limestone (Lower Eocene), between the lava flows and the Archaean basement. Where sampled, the Amarkantak lava pile consists of approximately $170 \mathrm{~m}$ of tholeiitic basalt with six flows recognized (see Paul et al. 2008). Hence, the Amarkantak flows constitute the basal members of the lava pile in the area. The third area sampled is Shahdol, some $50 \mathrm{~km}$ east of Umaria where the thickness of flows rarely exceeds $2-3 \mathrm{~m}$. These basal lava formations also overlie Gondwana sediments. Therefore, the flows in the three areas are basal members in the respective areas. But because of isolated occurrences, a stratigraphic correlation is not known.

A total of 15 mafic flows and seven dyke samples have been analysed for the PGE abundances (table 1) from a much wider collection of samples. Figure 1(a) shows the main localities and the location of the mafic dyke samples of the present study. It may be mentioned that no well exposed flows are found around Chirimiri. The samples of the flows which have been analysed for PGE are distributed over wide areas. Figure 1(a) shows the sample location of Shahdol flows and the analysed dykes from around Shahdol, Umaria and Chirimiri. There are no dykes around Amarkantak. Geological maps around Umaria and Amarkantak with the location of the analysed flow samples are shown separately in figure $1(\mathrm{~b}$ and $\mathrm{c})$. Umaria is about $55 \mathrm{~km}$ to the northeast of Shahpura and falls outside the map limit in figure 1(b). Both Shahpura and Umaria are shown in figure 1(a) for convenience of location. A general view of the flows in Umaria is shown in figure 2(a). As mentioned earlier, a correlation of the Umaria, Shahdol and the Amarkantak flows has not been possible because of disconnected exposures. Nor has it been possible to correlate the flows of the present study area from the EDVP with the well known flow formations of the Western Ghats (Cox and Hawkesworth 1985). Even a comparison of the western flows with the central Indian flow samples (cf. Peng et al. 1998) showed dissimilar geochemical characteristics. Mafic dykes occur at Shahdol and Chirimiri where they intrude the Gondwana sediments (figure $2 \mathrm{~b}$ ).

\subsection{Petrography}

The flows of the present study are essentially tholeiitic. The main minerals of the Umaria flows consist of plagioclase feldspar, clinopyroxene, olivine, opaque minerals and glass (figure 2c). Both clinopyroxene and plagioclase occur as phenocrysts and in the fine groundmass and display ophitic and subophitic texture. Fine plagioclase grains are enclosed in plagioclase phenocryst indicating different phases of plagioclase crystallization. The Shahdol flows are slightly coarser grained compared to the Umaria and Amarkantak samples. The dykes are coarse grained and, like the 


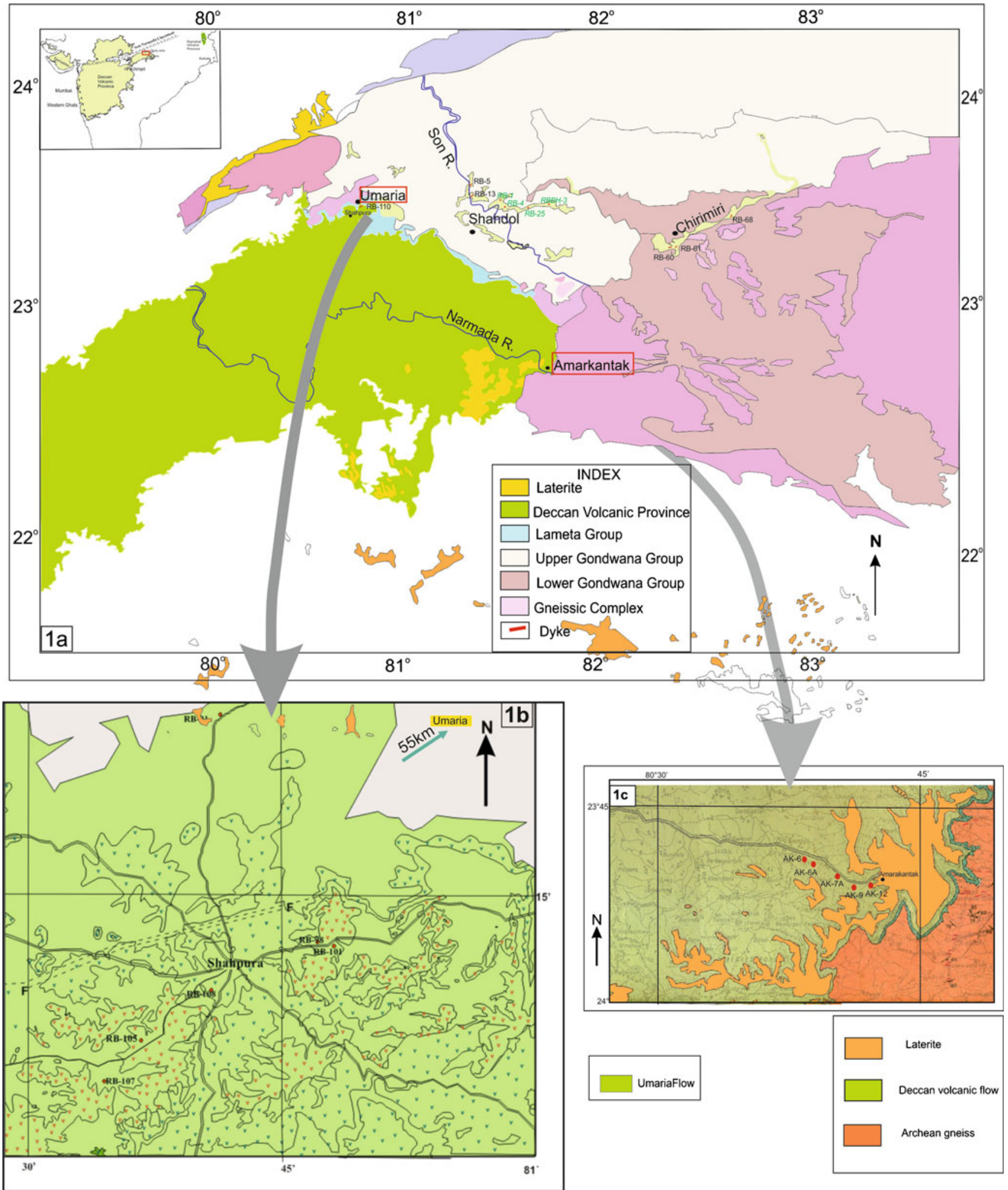

Figure 1. Geological map (after Geological Survey of India 2005) of the present study area in Eastern Deccan Volcanic Province. (a). The sample number of flows (shown in green colour and italicized) and the dykes around Shahdol, Umaria and Chirimiri are shown in this map. The flow samples from Umaria and Amarkantak are shown separately in (b) and (c). Note that the location of Umaria is $55 \mathrm{~km}$ northeast of Shahpura. The inset on the left top shows extent of Deccan Volcanic Province and the Rajmahal basalts. The analytical results of these samples are given in table 1. 


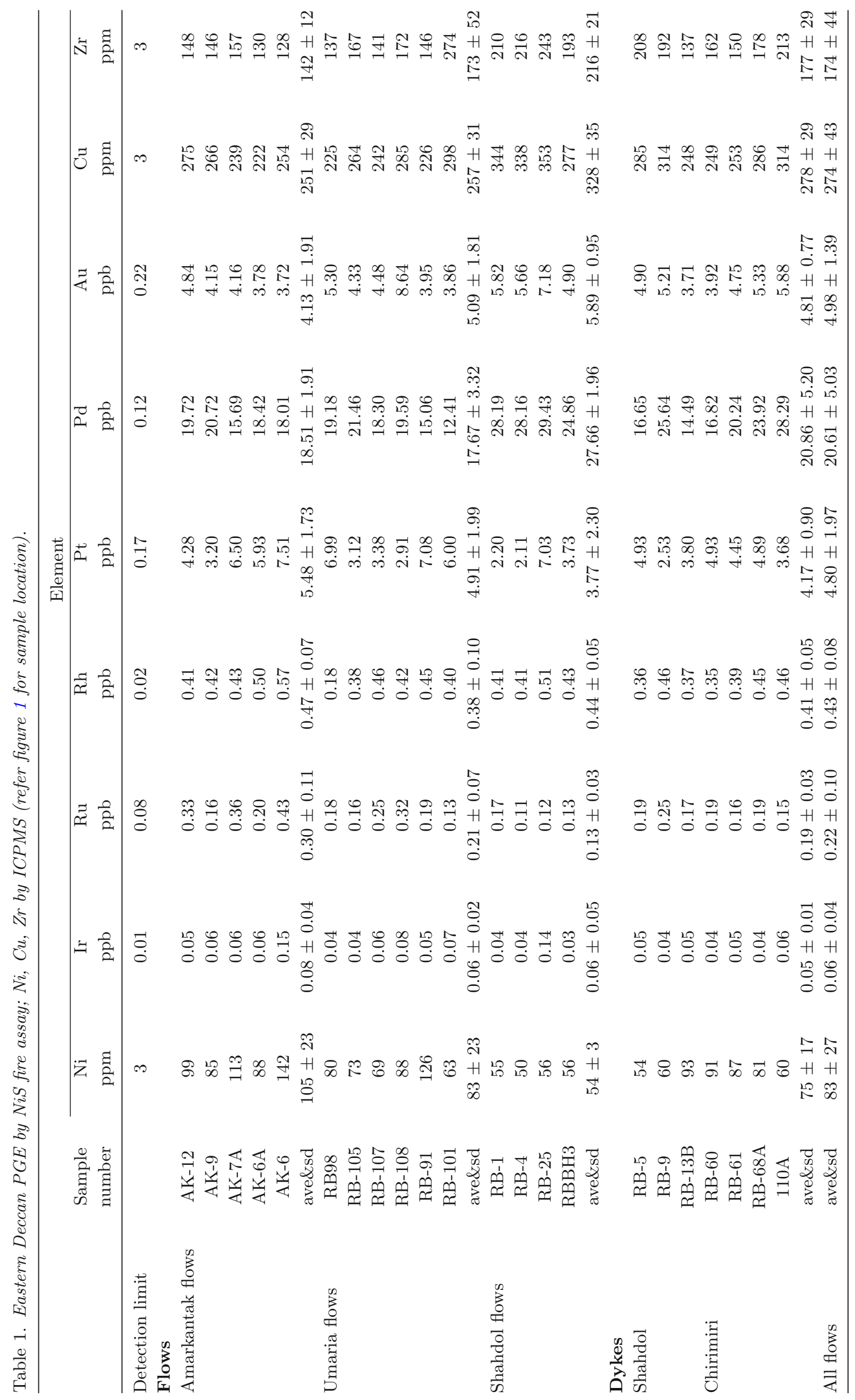



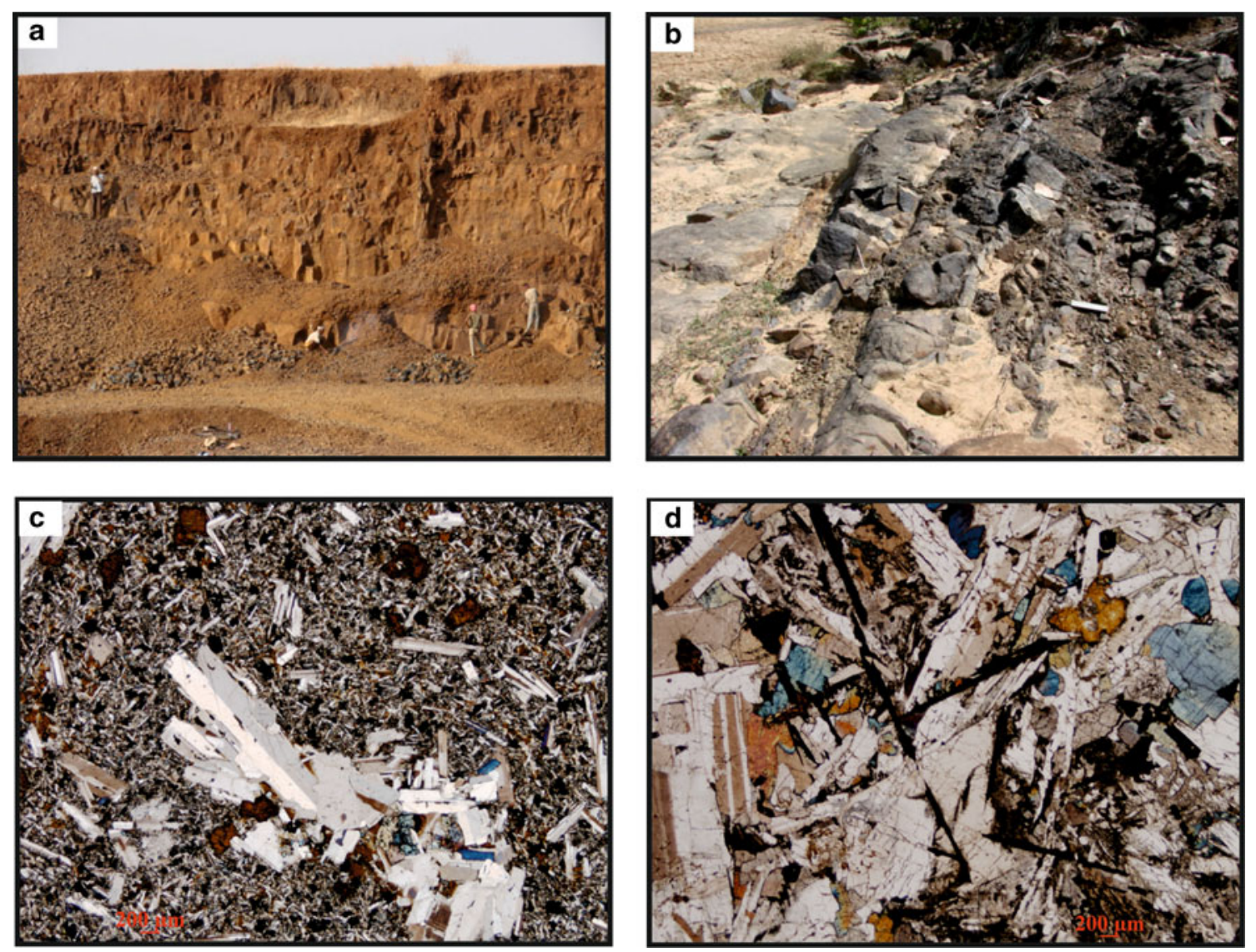

Figure 2. (a) A general view of Umaria flow. The contact between two flows are seen at the top, the lower flow shows columnar joints. (b) A mafic dyke in Son river bed in Shahdol. This dyke has apophyses in to the host Gondwana sediments. (c) Photomicrograph of a representative Umaria flow, with plagioclase of four different sizes, fine clinopyroxene and opaque minerals in the groundmass. Note that the large plagioclase phenocrysts have embayed margins. (d) Photomicrograph showing coarse grains of plagioclase, clinopyroxene, acicular ilmenite and anhedral magnetite. The texture indicates slower cooling rate than the flows.

flows, are composed of plagioclase, clinopyroxene, and opaque grains (figure 2d). Some of the clinopyroxene phenocryts are zoned with a magnesian-rich core and iron enrichment in the rims. Olivine is rarely present.

\subsection{Analytical notes}

Analyses for PGE and Au were carried out at the low-level PGE facility of the OntarioGeoscience Laboratories in Sudbury, Ontario. A nickel sulfide fire-assay which involved fusing $15 \mathrm{~g}$ of powdered rock with a mixture of $\mathrm{Ni}, \mathrm{S}, \mathrm{SiO}_{2}$, sodium carbonate and flour for 1.5 hours at $1050^{\circ} \mathrm{C}$ was used. The nickel sulfide button produced was dissolved in aqua regia, the solution converted to chloride and the PGE and Au collected by co-precipitation with tellurium. After dissolution of the Te in acid, PGE and $\mathrm{Au}$ were determined by inductively coupled plasma mass spectrometry (ICP-MS). Other elements including $\mathrm{Ni}, \mathrm{Cu}$ and $\mathrm{Zr}$ were determined on fresh rock powder subject to digestion in acids
$\left(\mathrm{HCl}, \mathrm{HNO}_{3}, \mathrm{HF}\right.$ and $\mathrm{HClO}_{4}$ ) for periods of up to 14 days in a closed beaker. Final analysis of this solution was by ICP-MS (see Jackson et al. 1990).

\section{Results and discussion}

Concentrations of PGE, $\mathrm{Ni}$ and $\mathrm{Cu}$ in 15 flows and seven mafic dykes are presented in table 1 . The flows were sampled from three sites including Umaria, Amarkantak and Shahdol. An average and a standard deviation are included for each location. Umaria and Amarkantak lava piles are some 400 and $170 \mathrm{~m}$ in thickness where sampled. In table 1, both are listed in stratigraphic order. For example, in the case of Amarkantak, the basal flow is AK-6 and the uppermost flow is AK-12. With the exception of $\mathrm{Au}$, the average PGE content in the Amarkantak pile is $21 \%$ higher than the average PGE in Umaria. The only metal with a lower average in the Amarkantak suite is Au. 
Table 2. A comparison of Ni, PGE, Au and $C u$ in the Amarkantak, Umaria and Shahdol flow domains; and in all flows and all dykes.

\begin{tabular}{lccc}
\hline Metal & $\begin{array}{c}\text { Amarkantak } \\
\text { vs. Umaria }\end{array}$ & $\begin{array}{c}\text { Amarkantak } \\
\text { vs. Shahdol }\end{array}$ & $\begin{array}{c}\text { Flows } \\
\text { vs. dykes }\end{array}$ \\
\hline $\mathrm{Ni}$ & +24 & +64 & +10 \\
$\mathrm{Ir}$ & +29 & +29 & +18 \\
$\mathrm{Ru}$ & +35 & +79 & +15 \\
$\mathrm{Rh}$ & +21 & +6.6 & +4.8 \\
$\mathrm{Pt}$ & +11 & +37 & +14 \\
$\mathrm{Pd}$ & +4.6 & -40 & -1.2 \\
$\mathrm{Au}$ & -21 & -35 & +3.5 \\
$\mathrm{Cu}$ & -2.4 & -27 & -1.5 \\
$\mathrm{Ave}$ & $+21 \%$ & $+43 \%$ & $+11 \%$ \\
\hline
\end{tabular}

Note: + indicates the Amarkantak lava pile has a higher \% of an element than either Umaria or Shahdol suites. - specifies elements higher in the Umaria or Shahdol piles. For the flow vs. dyke comparison the + sign indicates a higher $\%$ of an element in the dykes. Ave* is the average of Ni-PGE group abundances.

The concentrations of $\mathrm{Ni}, \mathrm{PGE}, \mathrm{Au}$ and $\mathrm{Cu}$ in different flow domains such as Amarkantak and Umaria are evaluated from the averages for each metal (table 1) and formulated as $100[(\Delta /(\mathrm{X} / 2)]$ where $\Delta$ is the difference in metal content and $\mathrm{X} / 2$ is the average concentration in the two domains. The result is in percent. A similar comparison can be made for metals in all flows and all dykes based on averages for all flows $(n=15)$ and all dykes $(n=7)$. In this case, six elements are higher in the flows compared with the dykes by an average of $11 \%$. Two metals, $\mathrm{Pd}$ and $\mathrm{Cu}$ (table 2, indicated by negative signs) are $1.2 \%$ and $1.5 \%$ higher in the dykes. The statistical significance of these very small percentages is low and the relatively small compositional difference suggests the dykes may be channels for flow movement.

Comparison of Amarkantak with Umaria and Shahdol flows finds that averages for Ni and PGE are $21 \%$ higher in the Amarkantak suite relative to Umaria flows and $43 \%$ higher compared to Shahdol flows. While $\mathrm{Pd}$ is higher in Amarkantak as compared to the Umaria suite, the difference is only 4.6\%. In comparison with Shahdol, Pd does not behave as the Ni-PGE group which is higher in Amarkantak lavas, but is much higher (40\%) in the Shahdol relative to Amarkantak flows. Palladium behaviour is comparable to that of $\mathrm{Au}$ and $\mathrm{Cu}$, and as a group, the elements $\mathrm{Pd}, \mathrm{Au}$ and $\mathrm{Cu}$ on average are 34\% higher in the Shahdol flows. In the case of $\mathrm{Pd}, \mathrm{Au}$ and $\mathrm{Cu}$, there is a reversal of behaviour in that these elements are higher in Umaria and Shahdol flows compared with Amarkantak flows. Specifically, $\mathrm{Au}$ and $\mathrm{Cu}$ are $21 \%$ and $2.4 \%$ higher in Umaria while $\mathrm{Pd}, \mathrm{Au}$ and $\mathrm{Cu}$ average $34 \%$ higher in Shahdol flows relative to Amarkantak.

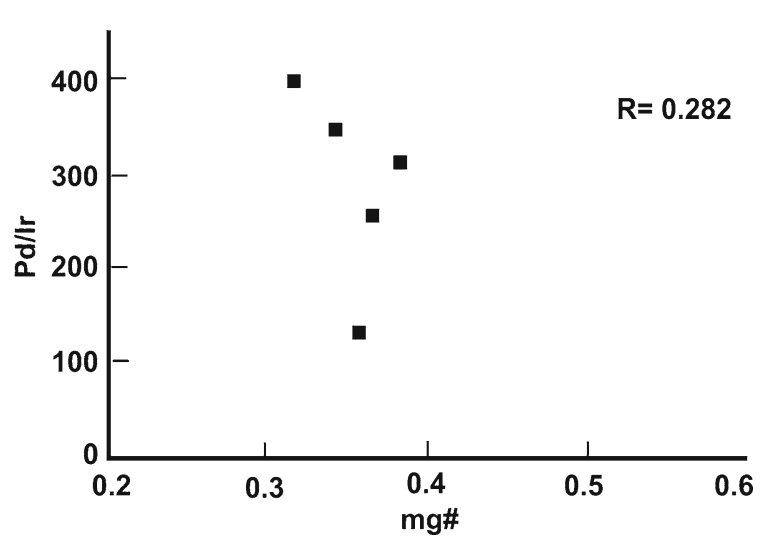

Figure 3. Scattergram of Pd/Ir vs. mg \# for the Amarkantak flow samples. Diagram shows a negative correlation between these two variables. Sample no. AK6 (table 1) which has higher Ir content falls away from the general trend.

A negative correlation between ( $\mathrm{Th} / \mathrm{Yb}) \mathrm{pm}$ and $(\mathrm{Nb} / \mathrm{Th}) \mathrm{pm}$, high initial ${ }^{87} \mathrm{Sr} /{ }^{86} \mathrm{Sr}$ ratio (0.70384-0.71208) and high $\mathrm{Ba}$ (70.6-224 ppm) in the Umaria samples suggest crustal contamination. There is no significant correlation between $(\mathrm{Th} / \mathrm{Yb}) \mathrm{pm}$ and $(\mathrm{Nb} / \mathrm{Th}) \mathrm{pm}$ in the Amarkantak samples, but the initial ${ }^{87} \mathrm{Sr} /{ }^{86} \mathrm{Sr}$ ratio is high (0.7037-0.7087) as also the $\mathrm{Ba}$ content (51-140 ppm). The crustally contaminated Bushe Formation of the western Deccan province has comparable initial ${ }^{87} \mathrm{Sr} /{ }^{86} \mathrm{Sr}$ ratio of 0.716 (Keays and Lightfoot 2010). Petrologically the basalt flow samples of the present study are tholeiitic and evolved with mg\# $\left[\mathrm{MgO} /\left(\mathrm{MgO}+\left(\mathrm{Fe}_{2} \mathrm{O}_{3} * 0.85\right)\right)\right]$ varying from 0.24 to 0.39 (Trisha Lala, Ph.D thesis under preparation). However, the Amarkantak flows have restricted mg\# from 0.32 to 0.38 (Lala, unpublished data). 
In the Amarkantak flow samples, $\mathrm{Pd} / \mathrm{Ir}$ ratio shows negative correlation with mg\# (figure 3). However, if all the flow samples of the eastern Deccan are plotted in the $\mathrm{Pd} / \mathrm{Ir}$ vs. mg\# diagram, there is a scatter of datasets.

The significance of sulfide saturation has been emphasized by Keays (1995) and Keays and Lightfoot (2010) with the latter authors comparing the Noril'sk Talnak area of Russia and the Deccan. A tool to address sulfide saturation is a two-component scattergram for which petrochemistry of each element is similar. The elements $\mathrm{Pd} v s$. Zr (figure 4) are plotted for the entire EDVP. Both elements behave in an incompatible manner with respect to the main phases involved in assimilation and fractional crystallization processes. However, similarity of behaviour breaks down if a phase is generated for which one of these elements is strongly compatible. An example could be the creation of a sulfide-rich liquid in mafic or ultramafic magma. The $\mathrm{D}$ value or partition coefficient for Pd with respect to partition between these two phases is expressed as $\mathrm{D}_{\mathrm{Pd}}^{\text {sulfide liquid/basic silicate melt }}=$ 36,000 (Crocket 2002, table 2; Fleet et al. 1999, table 6). If present, a sulfide-rich liquid would strongly concentrate the $\mathrm{Pd}$ but would not change the behaviour of $\mathrm{Zr}$ which has no known affinity for a sulfide liquid.

The correlation coefficient between $\mathrm{Pd}$ and $\mathrm{Zr}$ (figure 4) for all 22 EDVP samples is 0.78 as shown

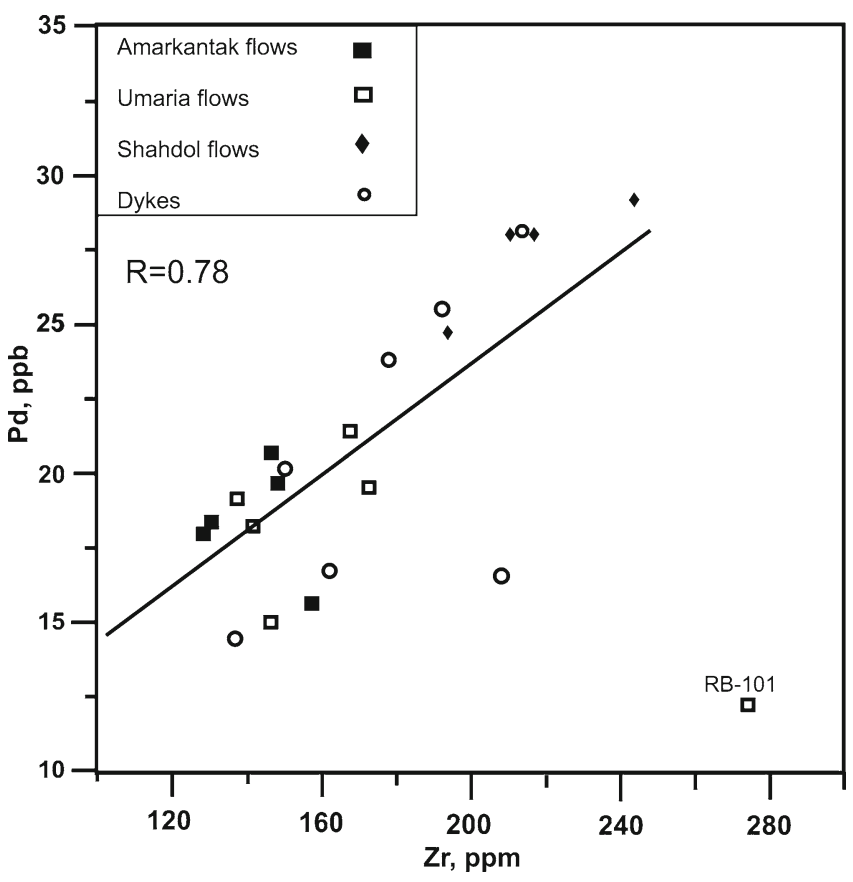

Figure 4. A scattergram of $\mathrm{Pd}$ (ppb) vs. Zr (ppm) for the entire suite of Eastern Deccan Volcanic Province (EDVP) flows and dykes and illustrating the offset of Umaria sample RB101. by the straight line fit. However, the labeled sample falls well off the correlation fit. The sample displaced is RB101, the basal sample from the Umaria pile. The measured analytical value of RB101 is $12.4 \mathrm{ppb}$ whereas the value suggested by the fit line is $\sim 31 \mathrm{ppb}$.

A very efficient extraction of $\mathrm{Pd}$ into a sulfiderich liquid would be expected as a response to the high $\mathrm{D}$ value of $\mathrm{Pd}-36,000$. A separation mechanism relying essentially on density difference between mafic-silicate magma and sulfiderich droplets could potentially be a significant factor in concentrating or localizing Pd-rich sulfide liquid. However, further research is clearly required to substantiate suggestions based on one sample.

\subsection{Comparison of primitive mantle profiles of western and eastern Deccan provinces}

Data used to compare western and eastern Deccan provinces are presented as averages in table 3 and include $\mathrm{Ni}, \mathrm{PGE}, \mathrm{Au}$ and $\mathrm{Cu}$. The western province constitutes the Western Ghats (Crocket and Paul 2004; Keays and Lightfoot 2010) and the Kutch Rift Basin (Crocket and Paul 2008) for a total of 59 samples. The eastern Deccan includes Amarkantak, Umaria, Shahdol and Chirimiri for a total of 22 samples and the averages are shown in table 1 . These data are normalized with respect to the primitive mantle values of McDonough and Sun (1995) as follows: Ir, Ru, Rh, $\mathrm{Pt}, \mathrm{Pd}, \mathrm{Au}$; Ni, Cu: 3.2, 5.0, 0.9, 7.1, 3.9, $1.0 \mathrm{ppb}$; 1960, 30 ppm.

The two profiles representing the western and eastern Deccan have steep positive slopes that are roughly subparallel but with three distinct domains recognizable. Nickel-Ir-Ru define a region at the lower end of the profiles where western ratios exceed those of the eastern samples by approximately two times (figure 5). A second region of more diverse character is defined by $\mathrm{Rh}$ and $\mathrm{Pt}$ in the middle of figure 5 . In this region, the two profiles intersect with $\mathrm{Rh}$ the lower and $\mathrm{Pt}$ the higher. Finally, at the upper end of the graph there is consistency of $\mathrm{Pd}, \mathrm{Au}$ and $\mathrm{Cu}$ with respect to relative content of metals in both eastern and western suites. In this region, the eastern Deccan suite has a higher content of these metals. The magnitude of the concentration is quite large with $\mathrm{Pd}$ higher by 2.2 times compared with 1.3 times higher in the case of $\mathrm{Au}$.

A significant feature of the primitive mantle normalized profiles in figure 5 is the difference in higher concentration shown by the $\mathrm{Ni}$ and of the eastern $\mathrm{Cu}$ ends of the graph. The Ni-Ir-Ru concentrations of the western Deccan exceed those Deccan 
Table 3. Average PGE, Au, Ni and Cu in the western and eastern Deccan Volcanic Provinces.

Western Deccan Volcanic Province

Western Ghats (Keays and Lightfoot 2010), $n=31$

\begin{tabular}{|c|c|c|c|c|c|c|c|c|}
\hline $\begin{array}{l}\mathrm{Ni} \\
\mathrm{ppm}\end{array}$ & $\begin{array}{c}\text { Ir } \\
\mathrm{ppb}\end{array}$ & $\begin{array}{c}\mathrm{Ru} \\
\mathrm{ppb}\end{array}$ & $\begin{array}{l}\mathrm{Rh} \\
\mathrm{ppb}\end{array}$ & $\begin{array}{c}\mathrm{Pt} \\
\mathrm{ppb}\end{array}$ & $\begin{array}{c}\mathrm{Pd} \\
\mathrm{ppb}\end{array}$ & $\begin{array}{c}\mathrm{Au} \\
\mathrm{ppb}\end{array}$ & $\begin{array}{c}\mathrm{Cu} \\
\mathrm{ppm}\end{array}$ & $\begin{array}{c}\mathrm{Zr} \\
\mathrm{ppm}\end{array}$ \\
\hline $98 \pm 53$ & $0.12 \pm 0.15$ & $0.44 \pm 0.38$ & $0.37 \pm 0.28$ & $7.11 \pm 7.27$ & $10.66 \pm 5.84$ & $4.58 \pm 4.79$ & $198 \pm 62$ & $150 \pm 37$ \\
\hline \multicolumn{9}{|c|}{ Western Ghats (Crocket and Paul 2004), $n=18$} \\
\hline \multicolumn{8}{|c|}{ Kutch (Crocket and Paul 2008), $n=10$} & $112 \pm 28$ \\
\hline $183 \pm 153$ & $0.11 \pm 0.09$ & $0.23 \pm 0.18$ & $0.17 \pm 0.18$ & $3.46 \pm 4.43$ & $5.48 \pm 8$ & $1.98 \pm 1$ & $121 \pm 79$ & $206 \pm 59$ \\
\hline \multicolumn{9}{|c|}{ Average Western Ghats and Kutch including flows, sills and dykes, $n=59$} \\
\hline $\begin{array}{l}111 \pm 74 \\
\text { Eastern De }\end{array}$ & $\begin{array}{l}0.10 \pm 0.12 \\
\text { can Volcanic }\end{array}$ & $\begin{array}{l}0.39 \pm 0.30 \\
\text { rovince }\end{array}$ & $0.32 \pm 0.23$ & $5.64 \pm 5.03$ & $10.14 \pm 7.94$ & $3.90 \pm 3.34$ & $192 \pm 80$ & \\
\hline \multicolumn{9}{|c|}{$\begin{array}{l}\text { Eastern Deccan Volcanic Province } \\
\text { Eastern Deccan Volcanic Province; all samples table } 1 \text {, this study, } n=22\end{array}$} \\
\hline $80 \pm 24$ & $0.06 \pm 0.03$ & $0.21 \pm 0.08$ & $0.42 \pm 0.07$ & $4.60 \pm 1.70$ & $20.69 \pm 4.96$ & $4.93 \pm 1.21$ & $275 \pm 39$ & $175 \pm 3$ \\
\hline \multicolumn{9}{|c|}{ Ratio of western Deccan (Western Ghats and Kutch) to eastern Deccan } \\
\hline $111 / 80$ & $0.10 / 0.06$ & $0.39 / 0.21$ & $0.32 / 0.42$ & $5.64 / 4.60$ & $10.14 / 20.69$ & $3.90 / 4.93$ & $192 / 275$ & \\
\hline 1.4 & 1.7 & 1.9 & 0.76 & 1.2 & 0.49 & 0.79 & 0.70 & \\
\hline
\end{tabular}

If the west/east ratio exceeds unity the western Province has higher average PGE values.

${ }^{*}$ The Western Ghats data of Crocket and Paul (2004) were obtained by radiochemical neutron activation whose sensitivity for $\mathrm{Ru}$ and $\mathrm{Rh}$ is poor in the context of multiple PGE analysis.

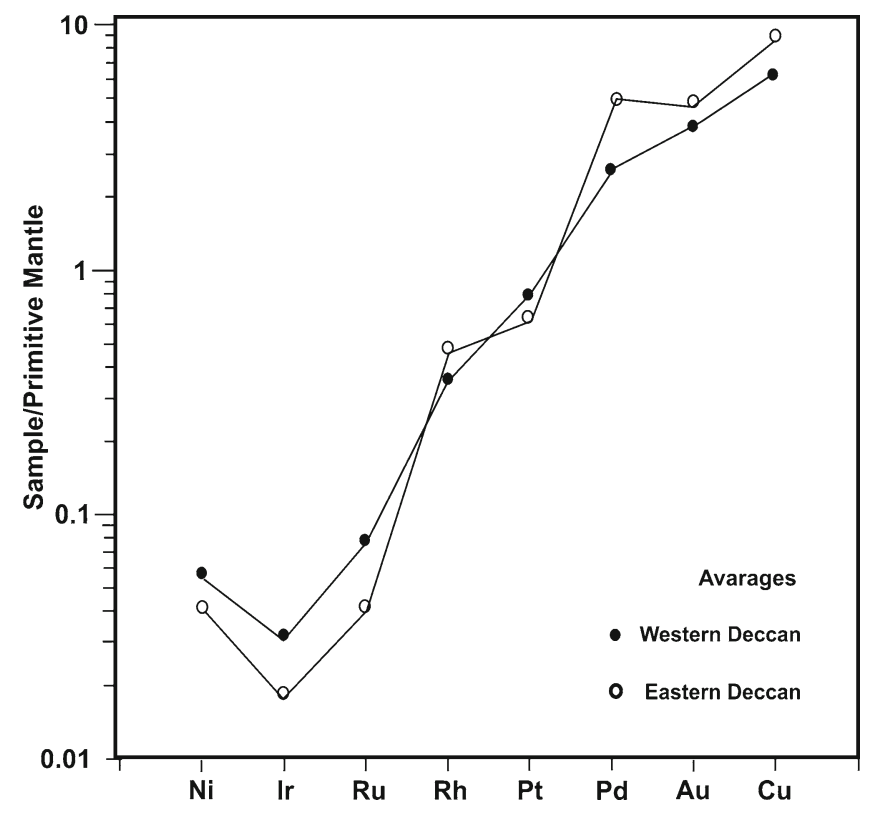

Figure 5. Primitive mantle normalized (after McDonough and Sun 1995) PGE-Au, Ni and Cu for east and west Deccan. Averages were taken from table 3 .

for the same elements whereas the reverse is the case for $\mathrm{Pd}-\mathrm{Au}-\mathrm{Cu}$ with the eastern Deccan recording the higher values. A number of factors, for example, percentage partial melting of the source rock and the temperature and pressure of partial melting probably strongly influence the character of these profiles. Further, Pd exhibits incompatible behaviour with respect to partition between olivine and mafic magma in contrast to Ir where

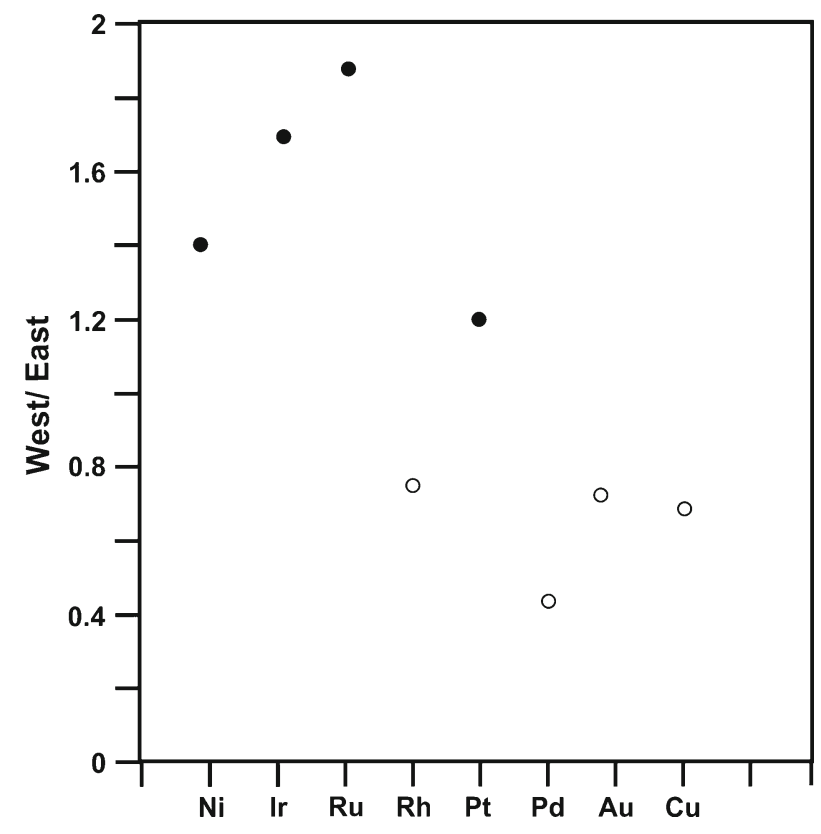

Figure 6. Plot of west/east ratios for PGE-Au, Ni and $\mathrm{Cu}$ taken from table 3. See text for explanation.

compatibility prevails between olivine and spinel and mafic magma (Righter et al. 2004).

It is accepted that IPGEs are not significantly fractionated by degree of partial melting but PPGEs are affected. Presence of minor PGEbearing phases in the mantle source region will significantly control the melt composition as the PGEs will be concentrated in the early melt. During subsequent fractionation, compatible IPGEs 
may be removed leaving relatively incompatible PPGEs in the evolving magma (Crocket 2002). The degree of partial melting has also been suggested to cause PGE variation in the flood basalts of Tarim basin, NW China (Li et al. 2012).

The western and eastern DVPs can also be compared using the data in table 3 where the western Deccan is defined as the average of the Western Ghats (Crocket and Paul 2004, 2008; Keays and Lightfoot 2010) and Kutch, and the eastern Deccan is represented by the averages in table 1 of this study. Table 3 allows a comparison by simply using the west/east DVP ratio for each element. Elements with ratios $>1$ (i.e., higher in the western Deccan) include $\mathrm{Ni}, \mathrm{Ir}, \mathrm{Ru}$ and $\mathrm{Pt}$, and are plotted in figure 6 as filled circles. Those with ratio $<1$ (lower in the western Deccan and higher in the eastern Deccan) are $\mathrm{Rh}, \mathrm{Pd}, \mathrm{Au}$ and $\mathrm{Cu}$, and are plotted in figure 6 as open circles.

With respect to PGE the western Deccan is represented by the Western Ghats and the Kutch. The eastern Deccan, some $600 \mathrm{~km}$ to the east and on the eastern margin on the Deccan province is seen in figure 1(a). In a study of the flood basalts of the Noril'sk district, Russia, Brügmann et al. (1993) propose that these basalts originate in deep chambers through assimilation and fractional crystallization processes. The primitive mantle normalized profiles of figure 5 are cross-cutting and show different groups of metals as dominant over different regions of the profiles. Thus, Ni-Ir-Ru are higher in the western Deccan while $\mathrm{Pd}-\mathrm{Au}-\mathrm{Cu}$ predominate in the eastern Deccan.

Subsurface transport of mafic magma has been argued in cases including the Mackenzie dyke swarm of the northwestern Canadian shield where some $2000 \mathrm{~km}$ of transport has been suggested (Baragar et al. 1996). Other examples include the study of Peng et al. (1998) where $900 \mathrm{~km}$ of transport in northeastern Deccan lavas is advocated. Deccan volcanic rocks attain a thickness of about $2 \mathrm{~km}$ in the Western Ghats and gradually thin down in the eastern part (e.g., $170 \mathrm{~m}$ in Amarkantak). Occurrence of $64.4 \mathrm{Ma}$ dyke in the $\sim 115 \mathrm{Ma}$ Rajmahal volcanic province together with the variation of the lava thickness in the DVP was interpreted as migration of the Deccan magma from west to east (Lala et al. 2011). These different PGE profile characteristics presented in this study probably result in part from a long distance of subsurface transport of Deccan magma from the west to east.

\section{Conclusions}

As part of a study on the Platinum-group element abundance of the large igneous province of
Deccan, four areas of Amarkantak, Umaria, Shahdol and Chirimiri from the eastern part of the province has been studied. The group of elements $\mathrm{Ni}, \mathrm{Ir}, \mathrm{Ru}, \mathrm{Rh}, \mathrm{Pt}$ and $\mathrm{Pd}$ have higher average contents in Amarkantak flows than in Umaria and Shahdol flows (tables 1 and 2), although $\mathrm{Pd}$ is only $4.6 \%$ higher. In fact, $\mathrm{Pd}$ does not behave like the Ni-PGE group but is much higher (40\%) in Shahdol flows than in Amarkantak flows. Palladium behaves like $\mathrm{Au}$ and $\mathrm{Cu}$. These three elements are 34\% higher in Shahdol flows compared with Amarkantak flows. Further, a plot of Pd vs. $\mathrm{Zr}$ shows a major diversion of one sample from the best fit line which opens a possible explanation of loss to immiscible liquid scavenging. A comparison of western Province which includes the Western Ghats and Kutch (figure 1a) and the eastern province using primitive mantle normalization showed that higher values prevailed in the western province suite in the $\mathrm{Ni}-\mathrm{Ir}-\mathrm{Ru}-\mathrm{Pt}$ region. In contrast, eastern province values dominated in the $\mathrm{Pd}-\mathrm{Au}-\mathrm{Cu}$ region at the ' $\mathrm{Cu}$ ' end of the profiles. A strong dominance of $\mathrm{Pd}$ in the eastern Deccan is documented. A number of factors, for example, percentage partial melting of the source rock and the temperature and pressure of partial melting and fractionating mineral phases probably strongly influence the character of these profiles.

\section{Acknowledgements}

This study was supported by the Department of Science and Technology, Government of India (Project No. ESS/16/236/2005). Reviews by two anonymous reviewers were helpful in shaping this manuscript as were the comments of Prof. T Ahmad, the Associate Editor.

\section{References}

Baragar W R A, Ernst R E, Hulbert L and Peterson T 1996 Longitudinal petrochemical variation in the Mackenzie Dyke Swarm, Northwestern Canadian Shield; J. Petrol. 37 317-359.

Brügmann G E, Naldrett A J, Asif M, Lightfoot P C, Gorbachev N S and Fedorenko V A 1993 Siderophile and chalcophile metals as tracers of the evolution of the Siberian Trap in the Noril'sk region, Russia; Geochim. Cosmochim. Acta 57 2001-2018.

Cox K G and Hawkesworth C J 1985 Geochemical stratigraphy of the Deccan Traps at Mahabaleshwar, Western Ghats, India, with implications for open system magmatic processes; J. Petrol. 26 355-387.

Crocket J H 2002 Platinum-group element geochemistry of mafic and ultramafic rocks; In: Geology, Geochemistry, Mineralogy and Mineral Benefication of Platinum-Group Elements (ed.) Cabri L J, Canadian Institute of Mining, Metallurgy and Petroleum, Special Volume, Montreal, Quebec, 54 177-210. 
Crocket J H and Paul D K 2004 Platinum-group elements in Deccan mafic rocks: A comparison of suites differentiated by Ir content; Chem. Geol. 208 273-291.

Crocket J H and Paul D K 2008 Platinum-group elements in igneous rocks of the Kutch rift basin, NW India: Implications for relationships with the Deccan volcanic province; Chem. Geol. 248 239-255.

Fleet M E, Crocket J H, Menghua L U A and Stone W E 1999 Laboratory partitioning of platinum-group elements (PGE) and gold with applications to magmatic sulfidePGE deposits; Lithos 47 127-142.

Geological Survey of India 2005 Geological map of Umaria and Shahdol.

Jackson S E, Freyer B J, Gosse W, Healey D C, Longerich H P and Strong D F 1990 Determination of the precious metals in geologic materials by inductively coupled plasma-mass spectrometry (ICP-MS) with nickel sulfide fire-assay collection and tellurium co-precipitation; Chem. Geol. 83 119-132.

Keays R R 1995 The role of komatiitic and picritic magmatism and S-saturation in the formation of ore deposits; Lithos 34 1-18.

Keays R R and Lightfoot P C 2010 Crustal sulfur is required to form magmatic Ni-Cu sulphide deposits: Evidence from chalcophile element signatures of Siberian and Deccan Trap basalts; Mineral Deposita 45 241-257.

Lala T, Chaudhary A K, Patil S K and Paul D K 2011 Mafic dykes of Rewa Basin, central India: Implication on magma dispersal and petrogenesis; In: Dyke swarms: Keys for Geodynamic Interpretation (ed.) Srivastava R K, Springer, pp. 141-166.

Li Y-Q, Li Z-L, Sun Y-L, Santosh M, Langmuir C H, Chen H L, Yang S-F, Chen Z-X and Yu X 2012 Platinum group elements and geochemical characteristics of the Permian Continental flood basalt in the Tarim basin, northwest China: Implications for the evolution of the Tarim Large Igneous Province; Chem. Geol. 328 $278-289$

McDonough W F and Sun S S 1995 The composition of the earth; Chem. Geol. 120 223-252.

Momme P, Tegner C T, Brooks C K and Keays R R 2002 The behaviour of platinum-group elements in basalts from the Greenland rifted margin; Contrib. Mineral. Petrol. 143 $133-153$.

Paul D K 2005 Petrology and geochemistry of the Salma dike, Raniganj coalfield (Lower Gondwana), eastern India: Linkage with Rajmahal or Deccan volcanic activity?; J. Asian Earth Sci. 25 903-913.

Paul D K, Lala T and Chaudhary A K 2008 Petrology and geochemistry of mafic flows and dykes of the eastern Deccan volcanic province, India; In: 33rd International Geological Congress, Abstracts section, MPI-05, Oslo, Norway.

Peng X, Mahoney J J, Hooper P R, Macdougall J D and Krishnamurthy P 1998 Basalts of the northeastern Deccan Traps, India: Isotopic and elemental geochemistry and relation to southwestern stratigraphy; J. Geophys. Res. 103 29,843-29,865.

Qi L, Wang C Y and Zhou M F 2008 Controls on the PGE distribution of Permian Emeishan alkaline and peralkaline volcanic rocks in Longzhoushan Sichuan Province, SW China; Lithos 106(3-4) 222-236.

Righter K, Campbell A J, Humayun M and Hervig R L 2004 Partitioning of $\mathrm{Ru}, \mathrm{Rh}, \mathrm{Pd}, \mathrm{Re}, \mathrm{Ir}$ and $\mathrm{Au}$ between Cr-bearing spinel, olivine, pyroxene and silicate melts; Geochim. Cosmochim. Acta 68 867-880. 